\title{
SOOME-EESTI KEELESILD XXI SAJANDIL
}

\author{
TÕNU TENDER, SVEN-ERIK SOOSAAR
}

$\mathrm{E}$

esti ja Soome suhted on olnud valdavalt sõbralikud ja tihedad (Eesti ja Soome suhete ajalugu). Nõnda tihedad, et mõnedki väljapaistvad kultuurija poliitikategelased on lähiminevikus kirjutanud või kõnelenud SoomeEesti ühisriigi loomise võimalikkusest ja vajalikkusest. „Eesti-Soome uniooni” ideenijõudis Gustav Suits 1917. aasta oktoobris (vt Undusk 2014: 34). Friedebert Tuglas tutvustas Suitsu Eesti-Soome uniooni mõtet detsembris 1917 (Tuglas 2011 [1917]). Jaan Unduski arvates pole välistatud, et see oli Eesti-Soome uniooni esimesi kajastusi Eestis, sest Suits ajas oma asja põhiliselt Helsingis ja taotles selle arutelu isegi Soome maapäeval (Undusk 2014). Konstantin Päts kõneles ja kirjutas ühisriigist $1918-1919^{1}$ ja uuesti oma n-ö poliitilises testamendis juulis 1940 (Zetterberg 2017, 2009: 383-384; Päts 2001 [1940]: 555). Pärast Eesti ja Soome iseseisvumist aastail 1917-1918 jõudsid suhted punkti, kus Eesti valitsus tegi Soomele ettepaneku liitriigi moodustamiseks. Soomes peeti tookord ja hiljemgi eelistatumaks, et Eesti säilitaks iseseisvuse (Eesti ja Soome suhete ajalugu). Eesti ja Soome omavaheliste sidemete kirjeldamiseks on kasutatud poeetilist kujundit Soome sild. ${ }^{2}$ Esiletõstmist väärib seegi, et Eesti ja Soome hümnil on senini ühine meloodia. 1869. aasta Eesti esimese üldlaulupeo kavasse kuulus ka eestikeelse tekstiga Fredrik Paciuse viisiga „Maamme” (Zetterberg 2004a: 52). Soome Vabariigi 99. sünnipäeva tähistamisel 7. detsembril 2016. aastal Soome Tallinna suursaatkonnas lauldi suursaadik Kristi Narineni ettepanekul Soome ja Eesti hümni samaaegselt eesti ja soome keeles: eestlased eesti ja soomlased soome keeles.

Mõlemad vabariigid tähistavad peagi 100. sünnipäeva. Kahe naaberriigi lähestikku seisvad tähtpäevad annavad põhjuse arutada, kas Soome silla veidi kitsendatud variandi - keelesilla - arendamine on noorema põlvkonna esindajate arvates vajalik.

\footnotetext{
${ }^{1}$ Päts tegi selle kava 1918. aasta kevadel, koostades ülevaate „Võimaliku Soome ja Eesti riikide liidu (liitriigi) alused” (Zetterberg 2004a: 53; Päts 2001a [1919], 2001b [1919]; Hytönen 2016).

${ }^{2}$ Seda poeetilist kujundit on tõenäoliselt esmakordselt kasutanud Fr. R. Kreutzwald eeposes „Kalevipoeg”, kus tammelaudadest ehitati sild üle Soome lahe: „Mis sest tammest tehtanessa? / Tüvist tehti tugev silda, / Painutati kena parve / Kahel aarul üle mere. / Üks viis saarelt Viru randa, / Teine aaru Soome randa, / Seep se kuulus Soomesilda" (Kreutzwald 1862, VI laul). Seda kõnekujundit kasutas mitmes oma luuletuses Lydia Koidula, nt 1881. aastal kirjutatud luuletsüklis „Soome sild”: „Rahu kõndis läbi laane / Õigusega paral kääl / Taara võlvis õnnekaane / Soome-Eesti pinna pääl / Silla otsad ühendatud / Kandes ühte isamaad / Tõe templiks pühendatud... / Nägu - millal tõeks saad?!” või siis: „Käsis kivi, kaenlus kannel, / Suguvennad, ühel vannel: / Tõusku Soome sild!! Üks meie sõna, üks meil meel, / üksainus meie mõte! // Õnn sulle, Soome silda!" jt (vt Zetterberg 2004b, 2017; Kiho 2014).
} 


\section{Soome-Eesti keelesillast}

Mis on või võiks olla Soome-Eesti keelesild $?^{3}$ Soome ja Eesti suhteid - sh nn keelesillaküsimusi - on mõne aasta eest käsitletud kahes ühisraportis. Jaak Jõerüüdi ja Esko Ollila 2003. aasta raportis (peatükis „Kultuur, haridus, teadus") on rõhutatud soome ja eesti keele õpetamist mõlemal pool Soome lahte: „2. Soome rajab Helsingi ülikooli juurde eesti keele ja Eesti Tartu Ülikooli juurde soome keele professuuri. 3. Eesti keele õpetamist Soome koolides tõhustatakse sel teel, et Soome kõrgkoolides sobiva üldettevalmistuse saanud eesti immigrantidest koolitatakse kiirkorras eesti keele õpetajaid koolidele ja ka vaba haridustöö tarvis. Soome keele efektiivsemaks õpetamiseks Eestis antakse eestlastest soome keele õpetajatele võimalus viibida Soomes ning süvendada oma teadmisi soome keele ja kultuuri alal.” (Jõerüüt, Ollila 2003: 7)

Põhjamaade Investeerimispanga asepresidendi Gunnar Oki ja Soome endise suursaadiku Eestis Jaakko Blombergi 2008. aastal koostatud ühisraport sisaldas kokku 55 ettepanekut ning koostajate visioone Eesti ja Soome suhetest aastaks 2030 (Eesti ja Soome suhete tulevikuraport valminud). Selleski ühisraportis on soome ja eesti keele oskusele ja keeleõppele tähelepanu pööratud:

Soodustada eesti keele õpetamist ja eestikeelse põhihariduse andmist Soomes ning soome keele õpetamist ja soomekeelse põhihariduse andmist Eestis (Okk, Blomberg 2008: 7);

Toetada kaasaegsete sõnaraamatute väljaandmist (Okk, Blomberg 2008: 9);

Naabermaa kultuuri vahetuks mõistmiseks on väga tähtis piisav keeleoskus. Valitsused peaksid toetama oma keele õpetamist ja õpetajate koolitamist naaberriigis. See nõuab vastava erikallakuga koolide ja ka eesti ja soome keele õpetajate koolituse toetamist. Koolid peavad lisama oma õppekavades naaberriigi ja selle kultuuri tutvustamist. Samuti tuleb tugevdada sama eesmärki teenivat sõpruskoolidevahelist koostööd.

Mõlemad maad peaksid koostöös toetama eesti ja soome kirjanduse tõlkimist naabermaa keelde ning tõlkijate koolitust. Nii igapäevase suhtlemise kui kultuurivahetuse seisukohalt on väga oluline ka kõrgetasemeliste sõnaraamatute olemasolu.

2003. aastal valmis Soome riigikeelte uurimiskeskuse (Kotimaisten kielten tutkimuskeskus) ja Eesti Keele Instituudi koostöös Soome-eesti suursõnaraamat (milles on 90000 märksõna). Eesti-soome suursõnaraamatu ettevalmistamine on mingil määral juba alanud, kuid töö käivitamiseks täies mahus puudub veel rahastus. Uus kõrgekvaliteetne sõnaraamat peaks olema kindlasti kõigile tasuta kättesaadav elektroonilisel kujul interneti vahendusel. Ka väikeformaadiga sõnaraamatud vajaksid uuendamist. (Okk, Blomberg 2008: 43)

Seega on mõlemas ühisraportis keelesilla all silmas peetud nii soome kui ka eesti keele oskust siin- ja sealpool Soome lahte. Soome ja eesti keel on õiguslikult võrdsed: mõlemad on riigikeeled ja Euroopa Liidu ametlikud keeled. Kuid kõnelejaskonna arvult on soome keelel eesti keele ees edumaa. Siinses

${ }^{3}$ Seda ei tohiks segi ajada Eestis tegutseva Soome Instituudi algatusel 2011. aasta juunikuus loodud soome keele ja kultuuri koostöövõrgustikuga Keelesild, mis tegutses aktiivselt aastatel 2011-2016, vt http://www.keelesild.ee/et/ (24. IV 2017). 
artiklis vaadeldakse eelkõige eestlastele soome keele õpetamist ja keeleoskust, soomlastele eesti keele õpetamine ja keeleoskus jääb siinse kirjutise fookusest välja.

Siinkirjutajadki mõistavad keelesilla all mõlema soome-ugri keele oskust nii Eestis kui ka Soomes. Kuid kas ka noorema põlvkonna esindajate arvates tähendab keelesilla arendamine sedasama? Kas võib juhtuda, et naaberriikide esindajate suhtlemisel kasutatakse tulevikus hoopis nüüdisaja lingua franca't - inglise keelt, nagu on viimasel ajal üha enam tavaks? See variant ei pruugi ilmvõimatu olla, kuid kas see oleks enam Soome-Eesti keelesild?

Ehk on tulevikus keelesillaks reaalajas toimuv masintõlge (vt nt Fišel 2016) ühest sugulaskeelest teise, st tekst või kõne tõlgitakse reaalajas soome keelest eesti keelde ja vastupidi? Võib-olla ongi soome-ugri keelte masintõlge tulevikus võimalik, kuid mitte veel lähiajal. Keelesild võib olla ka teatav kombinatsioon nendest võimalustest. Kirjutise eesmärk on selgitada, mida arvavad Soome-Eesti keelesillast praegused kooliõpilased, kes õpivad soome keelt teise ehk B-võõrkeelena. Esmalt vaatleme lühidalt Eesti elanikkonna soome keele oskust.

\section{Eestlaste soome keele oskusest rahvaloenduste põhjal}

Andmeid Eesti elanikkonna soome keele oskuse kohta annavad eri aegadel korraldatud rahvaloenduste $(1934,2000,2011)$ tulemused (vt Koreinik, Tender 2014; Tender 2010: 30).

Tabel 1 .

Eesti elanike keeleoskus 1934., 2000. ja 2011. aasta rahvaloenduse andmetel

\begin{tabular}{|l|r|r|r|r|r|r|}
\hline \multirow{2}{*}{ Keel } & \multicolumn{2}{|c|}{$\mathbf{1 9 3 4}$} & \multicolumn{2}{c|}{$\mathbf{2 0 0 0}$} & \multicolumn{2}{c|}{2011} \\
\cline { 2 - 7 } & $\begin{array}{c}\text { Oskajate } \\
\text { arv }\end{array}$ & Osakaal & $\begin{array}{c}\text { Oskajate } \\
\text { arv }\end{array}$ & Osakaal & $\begin{array}{c}\text { Oskajate } \\
\text { arv }\end{array}$ & Osakaal \\
\hline Vene keel & 197015 & $17,5 \%$ & 578004 & $42,2 \%$ & 545537 & $42,1 \%$ \\
\hline Inglise keel & 21793 & $1,9 \%$ & 345854 & $25,2 \%$ & 495420 & $38,3 \%$ \\
\hline Soome keel & $\mathbf{5 7 2 9}$ & $\mathbf{0 , 5} \%$ & $\mathbf{1 3 8 ~ 3 5 4}$ & $\mathbf{1 0 , 1} \%$ & $\mathbf{1 6 7 3 1 5}$ & $\mathbf{1 2 , 9} \%$ \\
\hline Saksa keel & 112938 & $10,0 \%$ & 140004 & $10,2 \%$ & 130191 & $10,1 \%$ \\
\hline Prantsuse keel & 13351 & $1,2 \%$ & 9912 & $0,7 \%$ & 18677 & $1,4 \%$ \\
\hline Läti keel & 16753 & $1,5 \%$ & 3072 & $0,2 \%$ & 2922 & $0,2 \%$ \\
\hline Muu(d) keel(ed) & 13164 & $1,2 \%$ & 26658 & $1,3 \%$ & 58017 & $4,5 \%$ \\
\hline Ei oska võõrkeeli & 851569 & $75,6 \%$ & 323950 & $23,6 \%$ & 369027 & $28,5 \%$ \\
\hline $\begin{array}{l}\text { Teadmata või ei } \\
\text { ole rakendatav }\end{array}$ & 1384 & $0,1 \%$ & $194140^{1}$ & $14,2 \%$ & $69203^{2}$ & $5,4 \%{ }^{3}$ \\
\hline
\end{tabular}

1 2000. aasta rahvaloendusel oli võõrkeeleoskuse küsimusele vastamine vabatahtlik, seetõttu jäi sellele küsimusele vastus saamata 194140 inimeselt, neist 102126 (ehk 52,6 \%) olid alla 15-aastased lapsed. Tõenäoliselt ei soovitud paljude laste ja vanurite puhul märkida vastust „ei oska”, vaid jäeti küsimusele lihtsalt vastamata.

${ }^{2}$ Sellest on keeleoskus teadmata 24182 juhul ning ei saa rakendada 45021 juhul (alla kolmeaastased).

${ }^{3}$ Sellest teadmata $1,9 \%$ ja ei saa rakendada $3,5 \%$. 
Tabelis 1 sisalduvad andmed näitavad, et soome keele oskajate hulk Eestis on ajavahemikus 1934-2011 märgatavalt kasvanud. 2000. aasta rahvaloenduse andmetel oskas 1370052 elanikust soome keelt 138354 (10,1\%). Eestlastest oskas soome keelt 132254 inimest (14,2\%). 2011. aasta rahvaloenduse andmetel leidus Eestis soome keele oskajaid esimest korda rohkem kui saksa keele oskajaid. Saksa keele populaarsus on pärast Teist maailmasõda nii Eestis kui ka mujal Euroopas vähenenud. Turu-uuringute AS-i viimase (jaanuar/ veebruar 2017) keelehoiakute uuringu järgi oli eesti keele oskajaid $84 \%$, vene keele oskajaid $71 \%$, inglise keele oskajaid $53 \%$, soome keele oskajaid $16 \%$, saksa keele oskajaid $9 \%$, prantsuse keele oskajaid $3 \%$, hispaania ja rootsi keele oskajaid mõlemaid $2 \%$.

Keeleoskuse andmeid rahvaloenduse põhjal hinnates tuleb arvesse võtta, et tegemist on subjektiivse enesehinnanguga, mis võib varieeruda suurel määral nii inimeste lõikes kui ka sama inimese erinevate eluperioodide lõikes (vt Koreinik, Tender 2014: 85).

\subsection{Eestlaste soome keele oskuse varieerumisest omavalitsustes}

2011. aasta rahvaloenduse andmetel oskas 1294455 Eesti elanikust soome keelt võõrkeelena 167315 inimest ehk 12,9\%. Sellega oli soome keel vene ja inglise keele järel levikult kolmas võoorkeel. Soome keele oskus on keskmisest suurem eesti emakeelega inimeste seas ja Harjumaal. Nii oli Harju maakonna omavalitsustes soome keele oskuse osakaal keskmiselt 18,75 \% (valdades 24,1\%), varieerudes Viimsi valla $30 \%$-st kuni Paldiski linna 6,8 \%-ni. Tallinnas, kus eestlaste osakaal kogu elanikkonnas oli $55,3 \%$, leidus soome keele oskajaid $17,6 \%$. Narva linna vastav näitaja oli $0,8 \%$ ja Ida-Virumaal tervikuna $2 \%$. Jõgeva maakonnas oli see $8,4 \%$, sh Jõgeva linnas 8,8 \%, Pärnu maakonnas $12,2 \%$ ja sh Pärnu linnas $13,9 \%$, Tartu maakonnas $9,4 \%$ ja sh Tartu linnas $9,8 \%$, Viljandi maakonnas $9,7 \%$ ja sh Viljandi linnas $11 \%$.

Eestlastest oskas soome keelt Harjumaal tervikuna $30,4 \%$ ja Tallinnas $30,8 \%$. Harjumaal oli soome keele oskajate osakaal Tallinnast kõrgem vaid Viimsi ja Harku valla eestlaste seas (vastavalt $35 \%$ ja $31,8 \%$ ). Teistes maakondades jäi eestlastest soome keele oskajate osakaal vahemikku 10-14 \%, alla $10 \%$ oli vaid Jõgeva (9 \%), Viljandi $(9,95 \%)$, Võru (8,9 \%), Põlva $(7,5 \%)$, Ida-Viru ja Valga maakonnas (mõlemas 7,45 \%).

\subsection{Eestlaste soome keele oskuse varieerumisest vanuserühmades}

Vanuserühmade kaupa on soome keele oskus kõige levinum keskealiste seas: vanuserühmas 30-49 aastat oskas soome keelt $23,4 \%$ kogu elanikkonnast, järgnesid 14,8 \%-ga vanuserühm 50-64 aastat, 12,3\%-ga vanuserühm 15-29 aastat, 6,3\% 65-aastased ja vanemad ning viimasena vanuserühm 3-14 aastat osakaaluga $0,6 \%$. Veelgi ilmekam on soome keele oskajate osakaal vanuserühmade kaupa eestlaste seas: vanuserühmas 30-49 aastat oskas soome keelt $32 \%$ kogu elanikkonnast, järgnesid 22,5 \%-ga vanuserühm 50-64 aastat, 15,4 \%-ga vanuserühm 15-29 aastat, 8,1\% 65-aastased ja vanemad ning viimasena vanuserühm 3-14 aastat osakaaluga $0,7 \%$. 
Kui vaadelda kogu rahvastikku 5-aastaste vanusekohortidena, ilmneb, et kõige suurem soome keele oskajate osakaal $(24,7 \%)$ on vanuserühmas $40-44$ aastat, ehk nende seas, kelle sünniaasta jääb vahemikku 1967-1971. Neile jääb ülinapilt alla (24,6 \%) vanuserühm 35-39 aastat, ehk nende seas, kelle sünniaasta jääb vahemikku 1972-1976. $20 \%$ piiri ületavad ka vanuserühmad 30-34 ja 45-49 aastat. Seega on soome keele oskuse kõige suurem osakaal nende seas, kelle lapse- ja noorukiiga jäi aastatesse 1970-1990. Nooremate seas hakkab soome keele oskajate arv kiiresti langema. Keeleoskuse selgitusena saab siin välja tuua kaks peamist tegurit: Soome televisiooni mõju lapse- või noorukieas vanuserühmas $35-44$ aastat ning täisealisena Soomes töötamisega saadud soome keele oskus kõigis vanuserühmades alates 20. eluaastast.

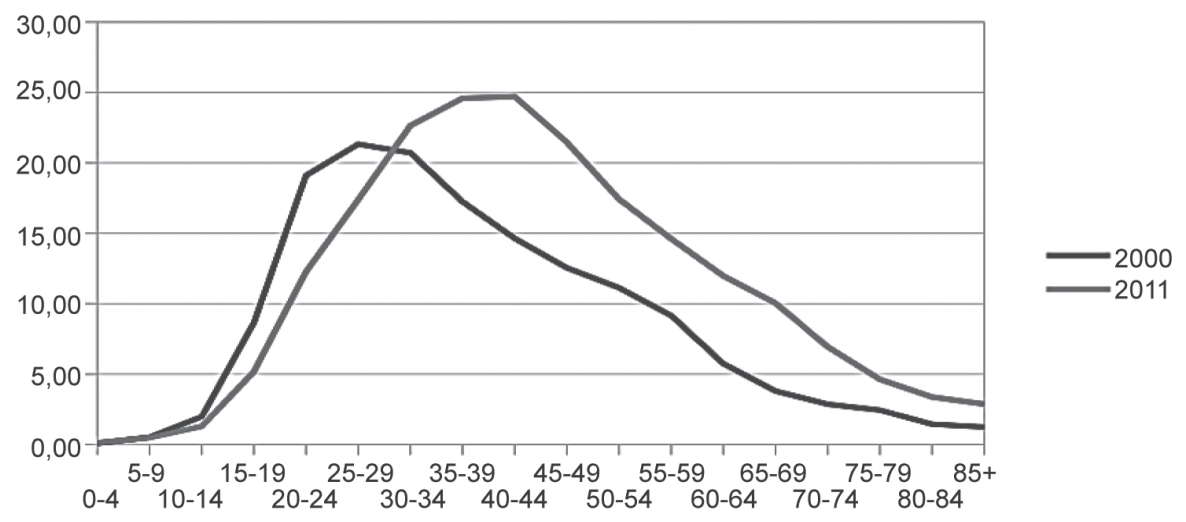

Joonis 1. Soome keele oskus Eestis vanusrühmade (5-aastased kohordid) kaupa 2000. ja 2011. aasta rahvaloenduse andmetel.

Vaatleme siinses kirjutises Eesti üldhariduskoolis soome keelt teise võõrkeelena õppivate õpilaste suhtumist soome keelesse võrreldes teiste keeltega. Kirjutise peaeesmärgiks on selgitada, kas neil on Soome ja soome keelega erisuhe? Kas nad hindavad soome keelt mingil põhjusel teistest keeltest kõrgemalt? Kas nad soovivad Soomes tööd leida? Või peavad soome keele õppimist mõne teise keele õppimisest kergemaks? Ülle Õis on kaitsnud Tallinna Ülikoolis 2014. aastal magistritöö „6.-8. klassi õpilaste soome keele õppimise motivatsioon ja soome keele õppes kasutatavad enese motiveerimise strateegiad" (Õis 2014). Magistritöös vaadeldakse mh õpilaste suhtumist soome keele õppimisse, kuid metodoloogia erinevuse tõttu ei ole selle tulemused otseselt võrreldavad käesoleva uurimuse tulemustega.

\section{Soome keele õppest teise võõrkeelena Eestis}

Eesti formaalharidussüsteemis on olnud traditsiooniks õppida kohustuslikult vähemalt kahte võorrkeelt, üldhariduskoolides õpetatakse-õpitakse tihti kolmandat ja neljandatki võõrkeelt. Võõrkeeleõppe tulemusi mõjutab olulisel määral asjaolu, mitmenda keelena, millise õpisisu ja tundide arvuga võõrkeelt õpitakse (Tender 2010: 36, 39). Uuendatud põhikooli riiklik õppekava (PRÕK 
2011) võimaldab õpetada ja õppida põhikoolis teise ehk B-võõrkeelena ükskõik millist võõrkeelt, arvestades kooli võimalusi ja õpilaste soove. ${ }^{4}$ Varem selline võimalus puudus: esimese ja teise võõrkeelena sai õppida nelja võõrkeelt (inglise, saksa, prantsuse, vene keelt) ning ülejäänud keeli, sh soome keelt, õpetati peamiselt kolmanda võõrkeelena ${ }^{5}$ (96 \% soome keele õppijaist), märksa vähem neljanda võõrkeelena (4 \% soome keele õppijaist) (Tender 2010: 38).

Õiguslikku võimalust õppida põhikoolis B-võõrkeelena ükskõik millist võõrkeelt on kasutatud peamiselt soome keele õpetamiseks. Positiivse arengu põhjused on soome keele õpetamise pikad traditsioonid C-võõrkeelena, tugev soome keele õpetajate võrgustik ning Soome Instituudi poolt pakutavad regulaarsed täienduskoolitused õpetajatele ja kultuuriprogrammid õpilastele, samuti ühiskonna suurem huvi soome keele õppimise vastu. Nt paljud lapsevanemad käivad Soomes tööl ja peavad seetõttu oluliseks, et nende lapsed õpiksid juba põhikoolis soome keelt. 2011/2012. õppeaastal alustatigi soome keele õpetamist 6. klassist teise võõrkeelena Viljandi Maagümnaasiumis (nüüd Viljandi Kesklinna Kool), Jõgeva Ühisgümnaasiumis (nüüd Jõgeva Põhikool) ja Tartu Mart Reiniku Gümnaasiumis (nüüd Tartu Mart Reiniku Kool'b). Neljanda koolina alustas 2012. aasta sügisel soome keele õpetamist B-võõrkeelena Pärnu Ülejõe Gümnaasium (nüüd Pärnu Ülejõe Põhikool). Seega ei ole teise võõrkeelena soome keelt õpetavaid koole ega soome keelt B-võõrkeelena õppivaid õpilasi just palju: soome keelt on teise võõrkeelena õppinud või õppimas u 200 õpilast. 2016/2017. õppeaastal alustati soome keele B-võõrkeelena õpetamist kolmes Tallinna koolis: Tallinna Ühisgümnaasiumis, Tallinna Lilleküla Gümnaasiumis ja Tallinna Kesklinna Vene Gümnaasiumis. Kuna õpilaste küsitlus toimus kevadel 2016, siis on Tallinna koolide õpilased uuringuvalimist välja jäänud.

\section{Küsimustik soome keele teise võõrkeelena õppijatele}

Koostasime 2016. aasta aprillis (st 2015/2016. õppeaastal) 13 küsimusega ankeedi, mille edastasime maikuus e-kirja teel koos lühikese selgitusega nende üldhariduskoolide soome keele õpetajatele, kus soome keelt õpetatakse teise võõrkeelena.

Küsitluse viisid läbi õpetajad. Vastused, st täidetud paberankeedid saime postiga 18., 19. ja 26. mail ning 15. juunil 2016. aastal.

Jõgeva Põhikooli ja Jõgevamaa Gümnaasiumi soome keele õpetaja Margit Alliksaare 63 soome keele õpilasest täitis ankeedi 60 õpilast. Ankeedi täitjate seas olid mh 5. klassi kõik 15 õpilast, kes 2016. a sügisel alles alustasid soome keele õppimist B-võõrkeelena; 6 . klassi 9 soome keele õppijast vastasid kõik 9; 7. klassi 6 soome keele õppijast vastas 5 (üks puudus); 8. klassi 20 soome keele õppijast vastas 19 (üks puudus); 9 . klassi 10 õpilastest vastas 9 (üks puudus);

${ }^{4} \mathrm{PRÕK}(2011) \S 15\left(3^{1}\right)$ ütleb, et eesti õppekeelega koolis või klassis õpitakse A-võõrkeelena inglise, prantsuse, saksa või vene keelt ning B-võõrkeelena inglise, prantsuse, saksa või vene keelt või muud võõrkeelt. Õpilase puhul, kes õpib eesti keelt teise keelena, ei ole kohustuslikku B-võõrkeelt.

${ }^{5}$ Huvitav näide pärineb Pärnu Kuninga Tänava Põhikoolist: seal õpetati 1990. aastatel 1. klassis soome keelt (tõenäoliselt fakultatiivainena, mitte A-võõrkeelena), 3. klassist alates inglise keelt (A-võõrkeelena) ning 6. klassist alates saksa või vene keelt (B-võõrkeelena).

${ }^{6}$ Soome keele õpetamisel on esinenud ka tagasilööke: probleemiks on olnud võimalus jätkata soome keele õppimist gümnaasiumiastmes. Peamiselt just seetõttu on soome keelt B-võõrkeelena pakkuvate koolide seast väljunud Tartu Mart Reiniku Kool. 
10. klassi (s.o juba gümnaasiumiastme $)^{7} 3$ soome keele õppijast täitsid ankeedi kõik õpilased.

Pärnu Ülejõe Põhikooli õpetaja Mare Soomere õpetas soome keelt 59 õpilasele, neist täitis ankeedi 52 õpilast.

Tartu Mart Reiniku Kooli õpetaja Tiiu Kruusi 15 soome keele õppijast täitis ankeedi 13 õpilast.

Viljandi Kesklinna Kooli õpetajate Kirsti Käiväräineni ja Maarika Roosimäe 79 soome keele õpilasest täitis ankeedi 63 õpilast. Kokku laekus meile 188 täidetud ankeeti, mis on $87 \%$ kõigist soome keele teise võõrkeelena õppijatest. Ankeeti ei täitnud eri põhjustel 28 õpilast, seega olnuks maksimaalne vastajate arv 216.

Analüüsisime vastuseid kombineeritud uurimismeetoditega. Kuna osa küsimustest eeldasid vastusena vastaja vaba teksti, siis uurisime neid kvalitatiivselt, ning küsimusi, mille vastuseks oli matemaatiline suurus, analüüsisime kvantitatiivselt kirjeldava statistikaga. Alljärgnevalt esitame tulemused küsimuste kaupa.

\subsection{Küsimused 1 ja 2. Vastajate geograafiline jaotus, vanus ja sugu.} 188 vastanust 60 oli Jõgevalt, 13 Tartust, 52 Pärnust ja 63 Viljandist. Vanuseliselt leidus kõige rohkem 15-aastaseid - 44, 13-aastaseid oli 38, 14-aastaseid 36,12 -aastaseid 29 ja 16 -aastaseid 27 . 11-aastaseid oli 13 . Vastajate vanuseline jaotus on näha joonisel 1. Vastajatest olid 100 tüdrukud (53\%) ja 88 poisid $(47 \%)$.

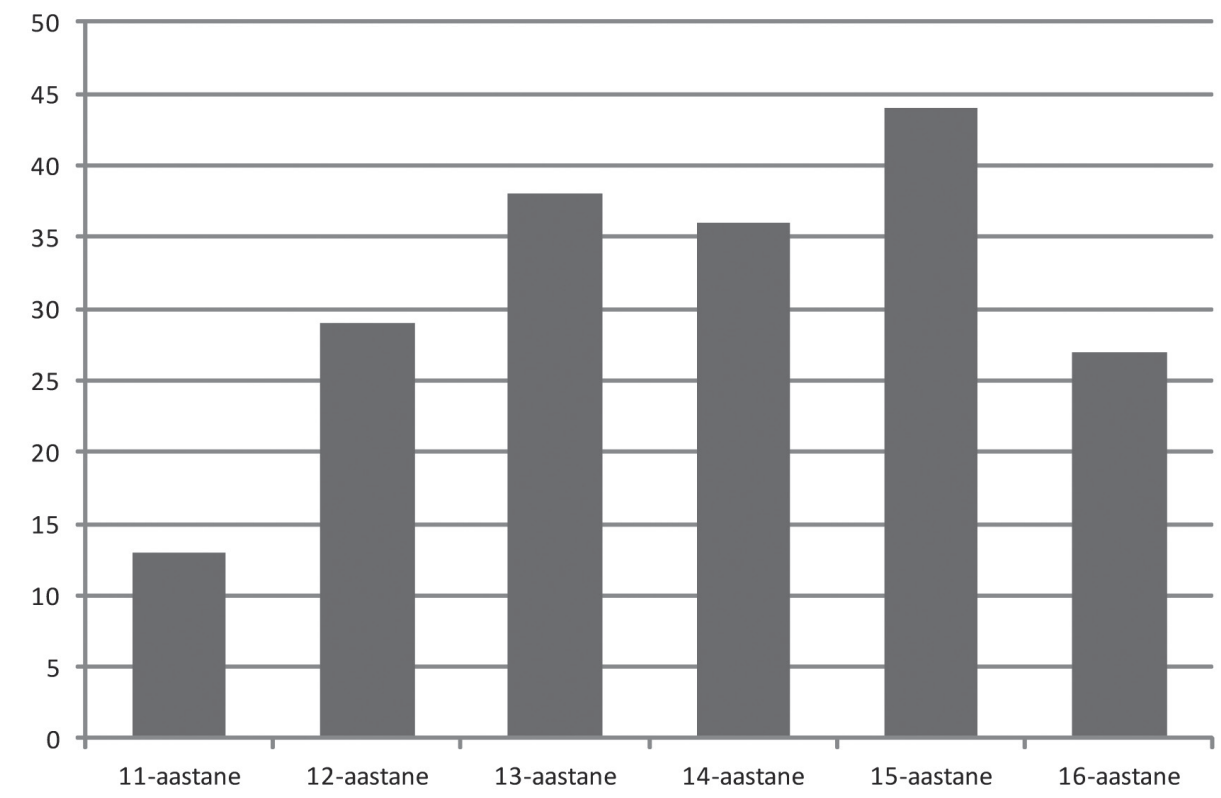

Joonis 2. Vastajate vanuseline jaotus.

\footnotetext{
${ }^{7}$ Gümnaasiumiastmes ei ole õppekava järgi tegemist enam esimese ehk A-võõrkeele ega teise ehk B-võõrkeelega, vaid õpetamine peaks toimuma keeletaseme rühmades, nt B1- ja B2-keeletaseme rühm.
} 


\subsection{Küsimus 3. Milline on Sinu kodune keel / kodukeeled, millega Sa oma vanematega suhtled?}

178 õpilase $(94,7 \%)$ kodukeel oli ainult eesti keel. Viie õpilase kodusteks keelteks olid eesti ja vene keel, kahel õpilasel eesti ja soome, ühel õpilasel vene keel, ühel õpilasel inglise keel ning üks õpilane nimetas oma kodukeelteks vene, eesti ja soome keelt. Seega oli neid, kelle kodukeel ei olnud eesti keel, vaid kaks õpilast (1\%), ja kaheksa õpilast (4,3\%) kasutas lisaks eesti keelele kodus ka mõnda muud keelt. Kolm õpilast nimetasid ühe koduse keelena ka soome keelt.

\subsection{Küsimus 4. Kas Sul on soomlasest sõpru või tuttavaid?}

Sellele küsimusele vastas jaatavalt $116(61,7 \%)$ ja eitavalt 72 õpilast. Paljud lisasid jaatavale vastusele ka täpsustuse, nt kirjasõber, isa (töötab), vend, vanaema, vanaisa, tuttav, mõlemaid jne. Neid, kes täpsustasid, et soomlasest sõbra või tuttava all peavad nad silmas mõnda sugulast, oli kümme. Need jätame arvestusest välja, kuna meid huvitab ennekõike see, kas neil on sõpru või tuttavaid väljaspool pereringi. Keskmisest veidi rohkem oli soomlastest sõpru või tuttavaid poistel ning Viljandi ja Pärnu õpilastel.

Tabel 2 .

Õpilaste hulk (arv) ja osakaal, kellel on soomlastest sõpru ja tuttavaid

\begin{tabular}{|l|r|r|c|c|c|r|}
\hline Linn & Ei & Jah & Osakaal & Sugulasi & $\begin{array}{c}\text { Ilma sugulasi } \\
\text { arvestamata }\end{array}$ & Osakaal \\
\hline Jõgeva & 26 & 34 & $56,7 \%$ & 4 & 30 & $50 \%$ \\
\hline Tartu & 5 & 8 & $61,5 \%$ & 1 & 7 & $53,8 \%$ \\
\hline Viljandi & 22 & 41 & $65,1 \%$ & 3 & 38 & $60,3 \%$ \\
\hline Pärnu & 19 & 33 & $63,5 \%$ & 2 & 31 & $59,6 \%$ \\
\hline
\end{tabular}

Soomlastest sõprade või tuttavate omamine ei olnud soome keele õppimise seisukohalt oluline: ilma sugulasi arvestamata oli soomlastest sõpru või tuttavaid $56 \%$-l vastajatest, kõikudes linnade arvestuses $50-60 \%$ vahel.

\subsection{Küsimus 5. Milline on Sinu esimene koolis õpitav võõrkeel ehk A-võõrkeel?}

Koolis õpitav esimene ehk A-võõrkeel oli pea kõigil vastanutel inglise keel, vaid üks märkis soome keele (arvatavasti oli ta kooliteed alustanud Soomes, sest Eesti koolides soome keelt esimese võõrkeelena ei õpetata). Ühe vastaja esimene võõrkeel oli hispaania keel (inglise keel oli ta emakeel) - ilmselt oli ta oma kooliteed alustanud väljaspool Eestit.

\subsection{Küsimus 6. Palun kirjuta üles Sinu arvates kõige tähtsam(ad) keel(ed) (kuni 6 keelt).}

Vastuses esinesid järgmised keeled: inglise - 180 korda, vene - 143, soome 132 , eesti -107 , saksa -73 , prantsuse -41 , hispaania -27 , rootsi -20 , hiina - 17, jaapani - 6, läti - 5, ladina - 3, türgi - 2; üks kord mainiti mandariini, aafrika ja india keelt (kaks viimast on geograafilised osutused, mitte keelenimetused), vt joonist 3. 62 korral kirjutati esimesena eesti keel, neist kahel korral oli eesti keel ainuke tähtsam keel. Seega pidas $60 \%$ neist, kes eesti keelt 
tähtsamate keelte seas nimetasid, seda enda jaoks kõige tähtsamaks keeleks. 103 vastajat nimetas esimesena inglise keelt, neist kuus nimetas ainult inglise keelt, kuid oli ka kaheksa vastanut, kes inglise keelt ei maininud. 17 vastajat nimetas esimesena vene keelt ja kuus soome keelt. Eesti keele vähene mainimine tuleneb ilmselt sellest, et osa õpilasi pidas küsimusele vastates silmas ainult võõrkeeli ega nimetanud seetõttu eesti keelt. Siiski võib oletada, et osa õpilastest ei peagi oma emakeelt tähtsaks. Vastustest võib järeldada, et inglise keel on soome keele õppijate seas ülekaalukalt tähtsaimaks peetav keel. Sellele järgneb vene keel ja kolmandana soome keel.

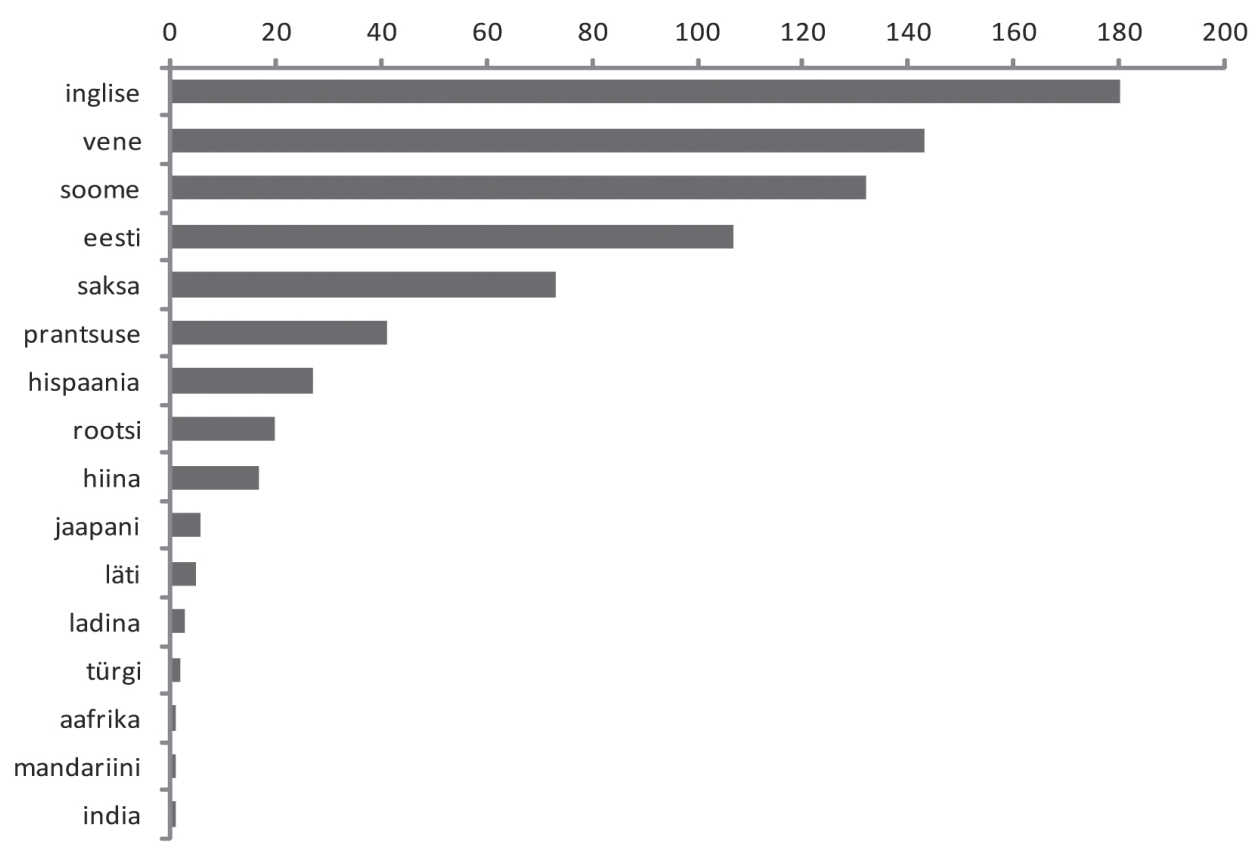

Joonis 3. Tähtsamate keelte nimetamiskordade arv (sh eesti keel).

\subsection{Küsimus 7. Miks Sa seda/neid tähtsaks pead?}

Kuna küsimusele sai vastata vaba tekstiga, siis varieerusid vastused küllaltki suures ulatuses. Siiski on võimalik välja tuua mõned olulisemad põhjused (vt joonist 4). Kõige sagedamini põhjendati valikut praktilise vajadusega: neid keeli läheb vaja elus või siis kitsamalt - töös, reisil või näiteks arvutimängus. Üle veerandi vastanutest põhjendas oma valikut sellega, et neid keeli räägitakse või kasutatakse palju, kas siis Eestis või mujal maailmas. 23 õpilast ehk $12 \%$ vastanutest väitis, et nende nimetatud keeltega saab elus hakkama. 14 tõi põhjenduseks, et see on nende emakeel, ja üks, et tegemist on riigikeelega. Neli vastajat tõi põhjuseks, et keel lihtsalt meeldib. Põhjusena nimetati näiteks „et ma ei näeks loll välja nendes riikides” või „tahan teiste maade inimestega rääkida”. 


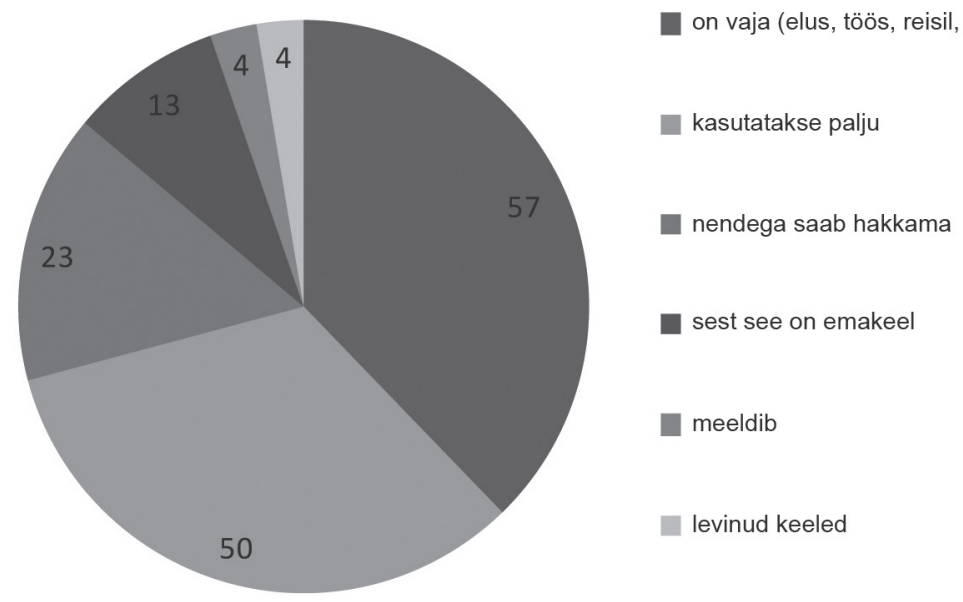

Joonis 4. Keel(t)e tähtsustamise olulisemad põhjendused.

\subsection{Küsimus 8. Kui kaua oled koolis soome keelt õppinud?}

153 vastanut oli õppinud soome keelt alates 6 . klassist, lisaks 15 Jõgeva 5. klassi õpilast, kes olid valinud soome keele teiseks võõrkeeleks ja pidid seda õppima hakkama 6. klassis. 17 Viljandi ja üks Pärnu õpilane alustasid soome keele õpinguid 5. klassis ja üks Viljandi õpilane 4. klassis. Üks Jõgeva õpilane oli õppinud soome keelt alates 1 . klassist.

\subsection{Küsimus 9. Kas soome keel on kergem või raskem võrreldes mõne teise võõrkeelega? (Näiteks inglise, saksa, prantsuse, vene või mõne muu keelega?) Palun too mõni konkreetne näide, mille poolest on soome keel võrreldes teiste keeltega kergem või raskem.}

Üldiselt peeti soome keelt teistest võõrkeeltest lihtsamaks. Sageli toodi võrdlusena (raskema keelena) välja vene keel, aga ka saksa, hiina ja prantsuse keel. Neist, kes soome keele raskust inglise keelega võrdlesid, leidsid 16, et soome keel on kergem, ja 28, et raskem kui inglise keel. 33 vastajat pidasid soome keelt vene keelest kergemaks. Lisaks mainis 11 õpilast, et soome keele tähestik on (vene keelest) kergem. Märkimisväärne ongi asjaolu, et õpilased nimetasid keele õppimise kerguse või raskuse puhul tähestiku erinevust. Tõenäoliselt on see üks silmatorkav tunnus, mida keelt tundmata on võimalik kindlaks teha. Kaks õpilast leidis, et soome keel pole ei kergem ega raskem kui muud võõrkeeled.

Põhjusena, miks soome keel on raskem kui inglise keel, toodi sageli välja, et seal on palju käändeid ja pöördeid ehk siis grammatika raskust, pikki sõnu ja keerulist hääldust. Lihtsuse selgitusena toodi välja sarnasust eesti keelega ja seda, et „tähestik on sama”. Inglise ja soome keele võrdluses mainiti sedagi, et inglise keel võib küll raskem olla, aga seda on kergem omandada, sest inglise keelega puututakse igapäevaelus rohkem kokku kui soome keelega. Vene kodukeelega laps pidas soome keelt kergeks, kuna see on eesti keelega sarnane. Soome keele puhul peeti probleemiks praktiseerimise võimaluste puudumist. 


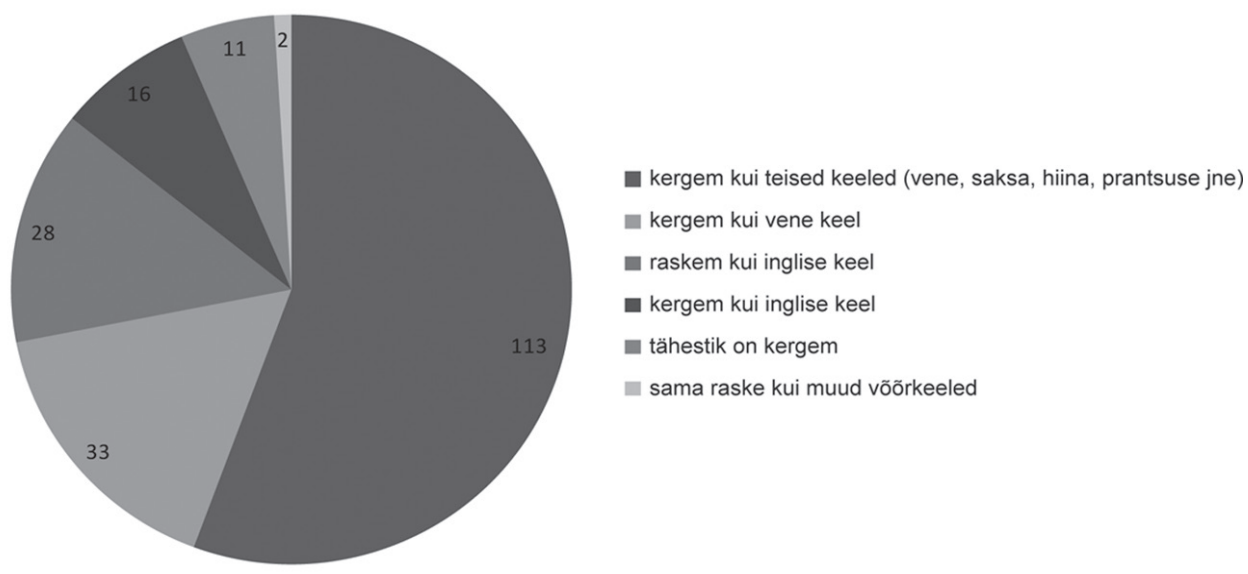

Joonis 5. Soome keele raskus võrreldes teiste võorrkeeltega.

\subsection{Küsimus 10. Miks valisid teiseks õpitavaks võõrkeeleks soome keele?}

Sellele küsimusele vastas ligi kolmandik õpilasi, et soome keel on võrreldes teiste valikuvõimalustega (peamiselt siis vene ja saksa keelega) kergem või lihtsam. 31 õpilast märkis, et soome keel on huvitav(am) kui vene või saksa keel, 29 tahavad Soome tööle ja elama minna. Kaheksa õpilast viitas valiku põhjusena mõne lähisugulase (ema, isa, õe, venna) soovitusele. Viis õpilast nimetas põhjusena seda, et soome keel on neile meeldiv, ja neli, et soome keel on põnev. Kolm õpilast vastas, et vene keelt nad juba oskavad ja seetõttu valisid soome keele (vastajate seas oli seitse õpilast, kelle üks kodukeeltest on vene keel). Kolm õpilast teatasid põhjusena, et vene keel neile ei meeldi.

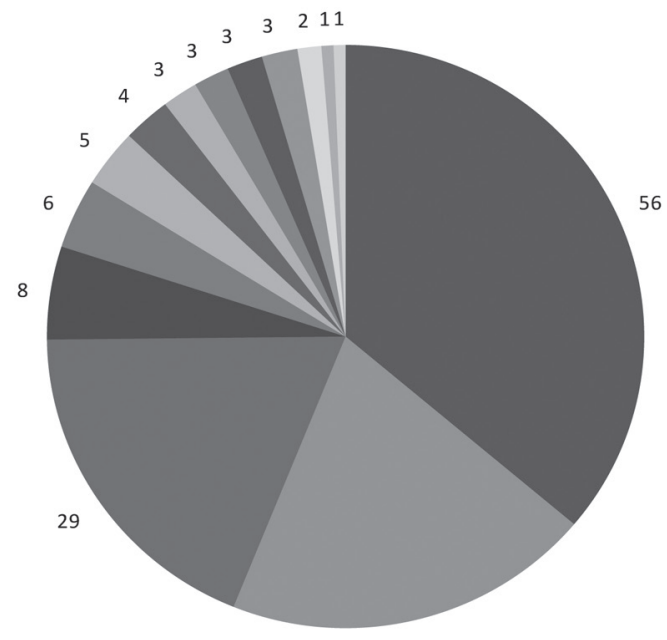

31
- see on $\operatorname{kerge}(m)$, lihtsam, lihtne

huvitav (huvitavam kui saksa/vene)

- tahab Soome tööle ja elama minna

n isa, ema v õde soovitasid

n eesti keelega sarnane

meeldib

n põnev (põnevam)

vene keelt juba oskab

- vene keele rühma ei mahtunud

vene keel ei meeldi

n juba oskab soome keelt

saksa keelt ei saanud

- teised keeled ei meeldi

- tahtsin olla teistest erinev

Joonis 6. Soome keele valiku põhjendused. 
Üksikud vastasid, et saksa keelt ei saanud mingil põhjusel õppida (kuigi oleks tahtnud), soome keele õpetaja oli hea või et õpilane tahtis olla teistest erinev. Üks õpilane vastas ka, et valis soome keele seetõttu, kuna juba oskas seda. Vastuste jaotust võib näha joonisel 6 .

Ülle Ôisi magistritöö aluseks olevas ankeedis on samuti küsimus soome keele õppimise põhjuste kohta. Õpilastel paluti valida 10-liikmelisest õpimotiivide loendist, mis jagatakse sisemisteks ja välimisteks motivatsioonifaktoriteks. Valikvastuste seas puuduvad käesoleva uurimuse põhjal kõige olulisemad põhjused (kuigi õpilane võis ka lisada põhjuseid, mida paljud tegidki, tuues välja just Soomes käimise või töötamise). Vastuste põhjal tehakse meie arvates ekslik järeldus, et soome keele õppimisel on olulised valdavalt sisemiselt motiveerivad faktorid (Õis 2014: 22, 25, 26).

\subsection{Küsimus 11. Millised on Sinu varasemad kokkupuuted soome keelega (nt kas oled seda õppinud, Soomes käinud või elanud, kas on vanemad Soomes elanud)?}

Sellele küsimusele vastas vaid 28 õpilast (15\%), et kokkupuuteid ei ole üldse või peaaegu üldse olnud. Ülejäänud vastajatel oli rohkem või vähem varasemaid kokkupuuteid. 15 oppilast ( $8 \%$ ) olid varem Soomes elanud, lisaks leidus neid, kes olid viibinud pikemat aega (kuu või paar) Soomes külas, enamasti Soomes elavate lähisugulaste juures. Paljud kirjutasid, et on Soomes (korduvalt) käinud. Leidus neidki, kes olid Eestis soomlastega kokku puutunud või mainisid Soome filmide nägemist. Ülevaate vastustest annab joonis 7 .

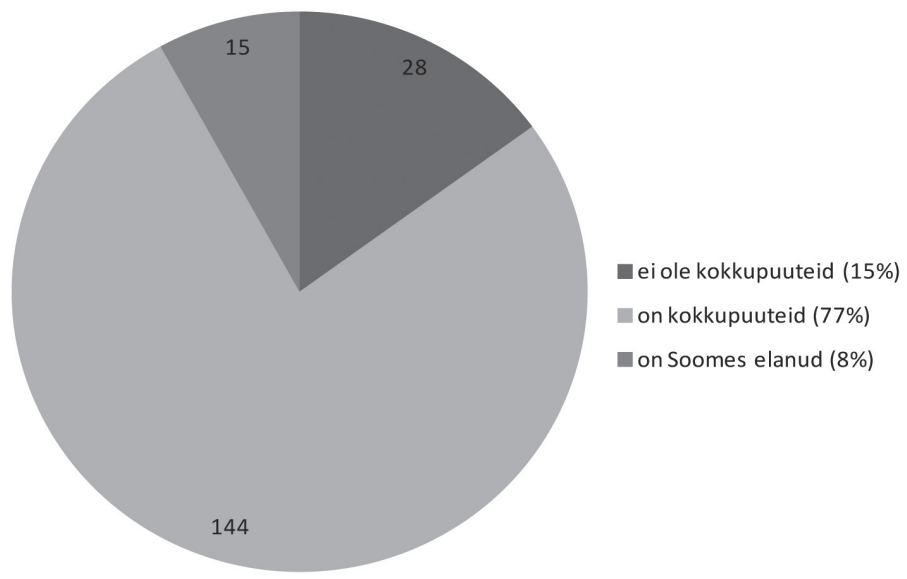

Joonis 7. Varasemad kokkupuuted soome keelega.

\subsection{Küsimus 12. Mida annab Sulle (praegu ja/või tulevikus) soome keele oskus? \\ Sellele küsimusele vastas 94 õpilast, et see annab võimaluse soomlastega suhelda. 68 vastajat rõhutas Soome elama või tööle mineku võimalust ning 27 arvas, et see hõlbustab töö leidmist või parema töökoha saamist, täpsustamata küll, millises riigis. Leidus üksikuid muidki variante, nt „mitte midagi”, „häid sõpru”, „ei tea”, „tulevikus näeb” jne.}


Seega hindavad pooled vastanutest soome keele oskuse peamiseks plussiks just suhtlemise võimalust soomlastega nende emakeeles. Teine pool peab oluliseks parema töökoha leidmise võimalust kas siis Eestis või Soomes. Piltliku ülevaate vastustest saab jooniselt 8 .

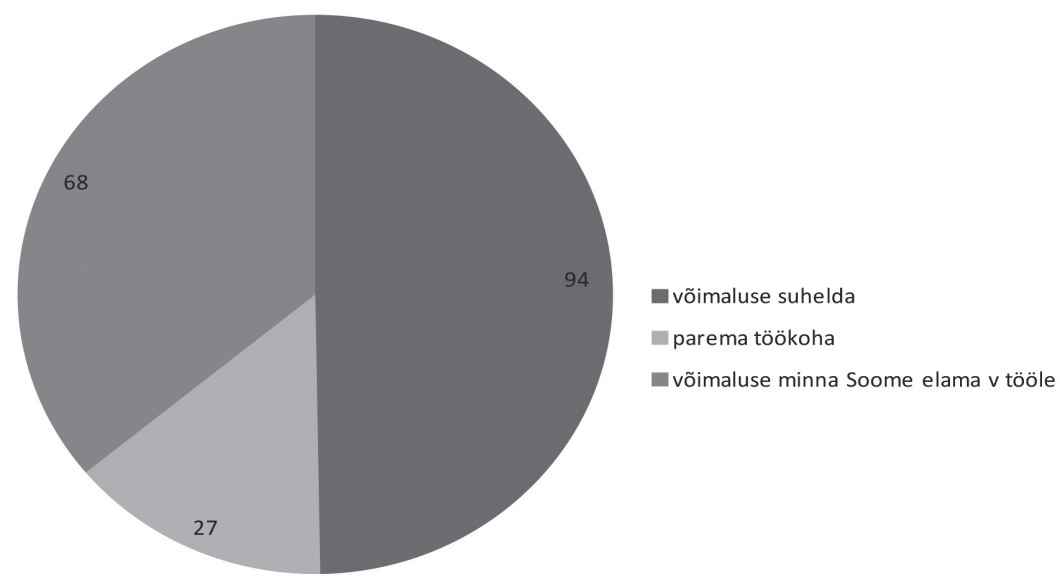

Joonis 8. Soome keele oskuse eelised.

\subsection{Küsimus 13. Mis keeles peaksid soomlane ja eestlane omavahel suhtlema? (Inglise, soome, eesti või mõnes muus keeles?)}

Tõenäoliselt ei saanud kõik õpilased küsimusest aru. Võib sedagi väita, et küsimuse sõnastus võimaldas selgest vastusest kõrvale põigelda. Päris palju vastati stiilis „keeles, mida mõlemad oskavad”. Inglise keelt nimetas 116 (62 \%), neist 51 kirjutas ainult inglise keelt, soome keelt $103(55 \%)$ ja eesti keelt 80 oppilast (43\%; vt tabelit 3). Vastati näiteks sedagi, et suhelda tuleks „soome, eesti ja inglise keele segus".

Tabel 3 .

Soomlase ja eestlase omavaheline suhtluskeel

\begin{tabular}{|l|c|c|}
\hline Keel & Osakaal & Vastajate arv \\
\hline Eesti keel & $42,55 \%$ & 80 \\
\hline Soome keel & $54,79 \%$ & 103 \\
\hline Inglise keel & $61,70 \%$ & 116 \\
\hline
\end{tabular}

Vastustes nimetas 37 õpilast kolme erinevat keelt, 54 kaht keelt, 76 piirdus ühe keele nimetamisega ning 21 vastajat ei nimetanud ühtegi konkreetset keelt (vt joonist 9).

Jõgeva 60 õpilasest nimetas vastuses soome keelt 30, Tartus vastavalt 13-st 7 õpilast, Pärnus 52-st 30 õpilast ja Viljandis 63-st 34 õpilast. Seega arvab kõigis linnades vähemalt pool kõigist soome keele kui teise võõrkeele õppijatest, et soomlane ja eestlane peaksid kasutama (või võiksid kasutada) omavahel suheldes ka soome keelt, kuigi inglise keel on kõigis küsitletud koolides ka eestlaste ja soomlaste vahelises suhtluses esikohal. 


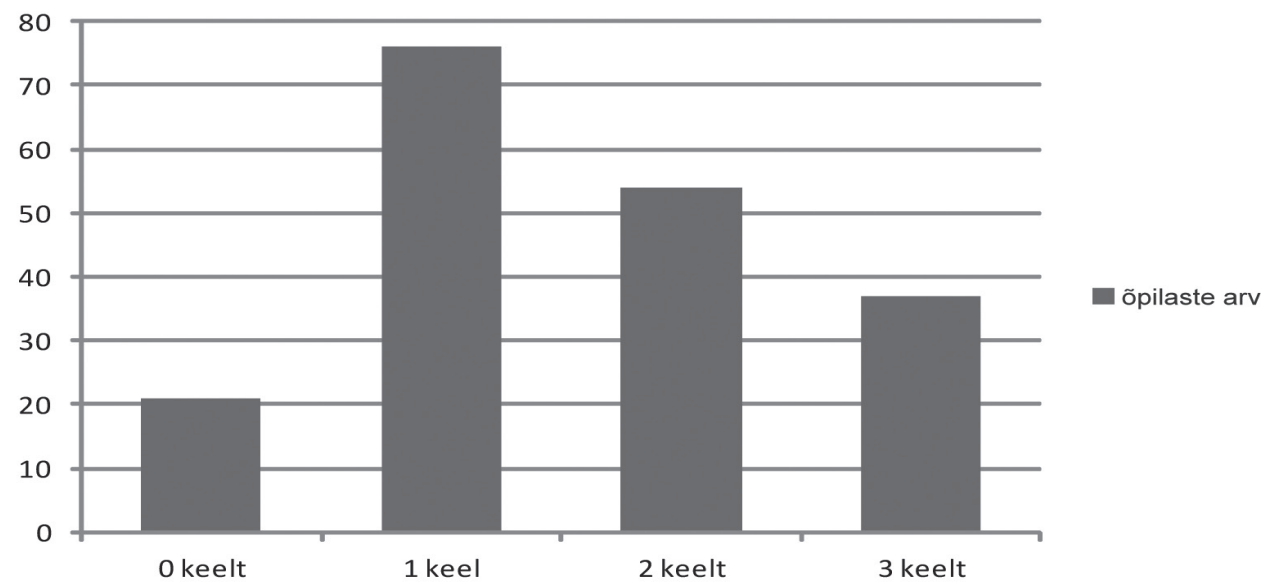

Joonis 9. Keelte arv, mida mainiti igas üksikus vastuses küsimusele „Mis keeles peaksid soomlane ja eestlane omavahel suhtlema?"

\section{Kokkuvõte}

Soome keele oskajate arv on Eesti ühiskonnas kolmveerandsajandiga kasvanud: kui 1934. aasta rahvaloenduse andmetel oskas soome keelt 0,5\% elanikkonnast (5729 inimest), siis 2011. aastal juba 12,9 \% elanikkonnast (167 315 inimest). Soome keele (tõenäoliselt suulise) oskuse kasv on seotud Eesti elanike tihedate sidemetega, sh Soomes töötamisega. Soome keelt on õpitud peamiselt väljaspool formaalharidussüsteemi, kuid seda on saanud õppida koolis kolmanda (vähem neljanda) võõrkeelena ning alates 2011. aastast ka teise võõrkeelena. Soome keele teise võorrkeelena õpetamise kogemus oli 2015/2016. õppeaastal neljal koolil ning soome keelt oli B-võõrkeelena õppinud või õppis 216 õpilast.

Soome-Eesti keelesillana on traditsiooniliselt mõistetud mõlema sugulaskeele oskust siin- ja sealpool Soome lahte. Kirjutise eesmärk oli selgitada, millistel kaalutlustel on õpilased valinud soome keele teiseks õpitavaks võõrkeeleks: kas seda peetakse mõne teise keele õppimisest kergemaks või raskemaks (viimasel juhul on tõenäoline, et kahe naaberriigi suhtluses eelistatakse tulevikus üha sagedamini inglise keelt), kas soome keelt hinnatakse mingil põhjusel teistest keeltest kõrgemalt või on valiku põhjuseks soov leida soome keele oskuse abil tööd.

Kuigi ankeedile vastanud õpilaste arvates on inglise keel kõige olulisem ja peamine suhtluskeel, peetakse oluliseks teistegi võorkeelte oskust, soomlastega suhtlemisel eelkõige soome keele oskust. Soome keele õppimise valikul pidas ligi kolmandik vastanutest lihtsustavaks asjaoluks selle sarnasust eesti keelega.

Mis keeles peaksid soomlane ja eestlane omavahel suhtlema? Päris palju vastati stiilis „keeles, mida mõlemad oskavad”. Inglise keelt nimetas 116 õpilast (62\%), neist 51 mainis ainult inglise keelt, soome keelt 103 (55\%) ja eesti keelt 80 õpilast ( $43 \%$ ). Vastati näiteks sedagi, et suhelda tuleks „,soome, eesti ja inglise keele segus”. Vastustes nimetas 37 oppilast kolme erinevat keelt, 54 
kaht keelt, 76 piirdus ühe keele nimetamisega ning 21 vastajat ei nimetanud ühtegi konkreetset keelt. Vähemalt pool nelja linna soome keele kui teise võõrkeele õppijatest arvas, et soomlane ja eestlane peaksid omavahel suheldes soome keelt kasutama. Samas oli inglise keel kõigis küsitletud koolides eestlaste ja soomlaste vahelises suhtluses esikohal.

Küsimusele, mida annab praegu ja/või tulevikus soome keele oskus, vastas $50 \%$ ehk 94 õpilast, et see annab võimaluse soomlastega suhelda. 68 vastajat (36 \%) rõhutas Soome elama või tööle mineku võimalust ning 27 arvas, et see hõlbustab töö leidmist või parema töökoha saamist.

Soome keele teiseks õpitavaks võõrkeeleks valimise küsimusele vastas ligi kolmandik õpilasi, et soome keel on võrreldes teiste valikuvõimalustega (peamiselt siis vene ja saksa keelega) kergem või lihtsam. 31 õpilast märkis, et soome keel on huvitav või huvitavam kui vene või saksa keel, 29 tahavad Soome tööle ja elama minna. Kaheksa õpilast viitas valiku põhjusena mõne lähisugulase (ema, isa, õe, venna) soovitusele. Viis õpilast nimetas põhjusena selle, et soome keel on neile meeldiv, ja neli, et soome keel on põnev. Kolm õpilast vastas, et vene keelt nad juba oskavad ja seetõttu valisid soome keele (vastajate seas oli seitse õpilast, kelle üks kodukeeltest on vene keel).

Eesti mitmekeelsuse traditsiooni säilimise ning keelesilla arendamise huvides on siinse kirjutise autorite arvates nii soome kui ka eesti keele õppimine ja õpetamine mõlemal pool Soome lahte jätkuvalt vajalik ja aktuaalne. Samuti on aktuaalsed kahes nn ühisraportis - Jaak Jõerüüdi ja Esko Ollila (2003) ning Gunnar Oki ja Jaakko Blombergi (2008) raportis - keelesilla edendamiseks pakutud meetmed. Näiteks Oki ja Blombergi ühisraport pidas oluliseks eesti ja soome suursõnaraamatu koostamist ning tasuta kättesaadavaks muutmist elektroonilisel kujul interneti vahendusel (Okk, Blomberg 2008: 43). See soovitus peaks kahe riigi keeleteadlaste ühistööna realiseeruma Eesti Vabariigi 100. sünnipäevaks.

Soome keele õppimise võimalust Eesti haridussüsteemis tuleks laiendada ning õpilastele peaks pakkuma võimalust soome keele õpingutega gümnaasiumiastmel jätkata.

Kirjutise aluseks on 29. X 2016 Võru „Kandles” Võru Instituudi ja Tartu Ülikooli 20. läänemeresoome sügiskonverentsil peetud ettekanne „Soome-Eesti keelesilla rajamise võimalikkusest ja vajadustest” ning 8. IV 2017 Tartu Ülikooli Narva Kolledžis 5. Mikael Agricola päeva konverentsil peetud ettekanne „Tõusku Soome sild!?”. Akadeemikud Jaan Undusk ja Tõnu-Andrus Tannberg juhatasid siinse kirjutise autorid mõne olulise publikatsioonini. Filosoofiadoktor Kadri Koreinik aitas täpsustada kooliõpilaste küsimustikku. Soome Instituudi Eestis toonane keeleprogrammi juht Maarja Keba vahendas artikli autoritele Eesti üldhariduskoolide soome keele õpetajate kontakte. Õpetajad Margit Alliksaar, Mare Soomere, Tiiu Kruus, Kirsti Käiväräinen ja Maarika Roosimägi palusid oma soome keele õpilastel küsimustele vastata ning edastasid kogutud vastused siinkirjutajatele. Suur tänu kõigile abilistele! 


\section{Kirjandus}

Eesti ja Soome suhete ajalugu. http://www.estemb.fi/est/eesti_ja_soome/suhete_ ajalugu (1. III 2017).

Eesti ja Soome suhete tulevikuraport valminud. - Uudised 26.06.2008. Soome Suursaatkond Tallinnas. http://www.finland.ee/public/default.aspx?contentid=1 $52698 \&$ nodeid=40599\&contentlan=13\&culture=et-EE (6. IV 2017).

Fiš el, Mark 2016. Milline on hea masintõlge? - Sirp 11. III. http://www.sirp.ee/ s1-artiklid/varia/milline-on-hea-masintolge/ (20. IV 2017).

Hytönen, Patrik 2016. Soome presidentide visiitide mõju Eesti-Soome suhetele aastail 1918-1940. Bakalaureusetöö. Tartu Ülikooli Humanitaarteaduste ja kunstide valdkond. Ajaloo ja arheoloogia instituut. Uusima aja osakond. http:// hdl.handle.net/10062/54108

Jõ er üüt, Jaak, Ollila, Esko 2003. Eesti ja Soome Euroopa Liidus. Soovitused. Tallinn: Riigi Teataja Kirjastus. http://vm.ee/sites/default/files/content-editors/ web-static/437/Eesti_soome_\%20ek.pdf (5. III 2017).

Keelehoiakute uuring. Küsitlus 15-74aastaste elanike seas. Jaanuar/veebruar 2017. Turu-uuringute AS. https://www.hm.ee/sites/default/files/aruanne.pdf (31. VIII 2017).

Kiho, Toomas 2014. Soome silda paugatie. - Postimees 11. IX. http://arvamus. postimees.ee/2916879/toomas-kiho-soome-silda-paugatie (1. III 2017).

Korein ik, Kadri, Tender, Tõnu 2014. Eesti keeltest rahvaloendustel. - Emakeele Seltsi aastaraamat 59 (2013). Tallinn: Teaduste Akadeemia Kirjastus, lk 77-102.

O k k, Gunnar, B l o m b e r g, Jaakko 2008. Eesti ja Soome koostöö võimalused 2008. Tallinn: Eesti Välisministeerium. http://www.digar.ee/id/nlib-digar:39566 (5. III 2017).

PRÕK $2011=$ Põhikooli riiklik õppekava. https://www.riigiteataja.ee/ akt/129082014020 (30. IV 2017) ja Vabariigi Valitsuse 6. jaanuari 2011. a määrus nr 1 „Põhikooli riiklik õppekava” Lisa 2 (muudetud sõnastuses). https:// oppekava.innove.ee/pohiharidus/voorkeeled/ (30. IV 2017).

Päts, Konstantin 2001a [1919]. Soome-Eesti. - K. Päts, Eesti riik II. (Eesti mõttelugu 38.) Koost Toomas Karjahärm, Hando Runnel. Tartu: Ilmamaa, lk 54-56.

Päts, Konstantin 2001b [1919]. Suur-Soome. - K. Päts, Eesti riik II. (Eesti mõttelugu 38.) Koost Toomas Karjahärm, Hando Runnel. Tartu: Ilmamaa, lk 57-59.

Päts, Konstantin 2001 [1940]. Vana riigimehe oppetused uuele Euroopale. K. Päts, Eesti riik II. (Eesti mõttelugu 38.) Koost Toomas Karjahärm, Hando Runnel. Tartu: Ilmamaa, lk 555-556.

Rahva ja eluruumide loendus 2011. Statistikaamet. Statistika andmebaas http://pub.stat.ee/px-web.2001/Database/Rahvaloendus/databasetree.asp (18. IX 2017).

Z et t e r b e r g, Seppo 2004a. Ühe puu eri harud. Eesti ja Soome - eilsest tänasesse. (EVA raport.) Tlk Kulle Raig, Ruta Rannat. [Helsinki:] Taloustieto.

Zetterberg, Seppo 2004b. Soome sild kui mitmetähenduslik sümbol. - Uudised 24.11.2004. Soome Suursaatkond Tallinnas. http:/www.finland.ee/public/ default.aspx? contentid=147796\&nodeid=40600\&contentlan=13\&culture=et-EE (1. III 2017).

Z ett e rberg, Seppo 2009. Eesti ajalugu. [Tallinn:] Tänapäev. 
Zetterberg, Seppo 2017. Mõte Soome ja Eesti kaksikriigist. - Postimees AK 8. IV, nr 422, lk 8-9. http://arvamus.postimees.ee/4069957/seppo-zetterberg-mote-soome-ja-eesti-kaksikriigist?_ga=1.197243567.1235895031.1486396 404 (23. IV 2017).

Tender, Tõnu 2010. Mitmekeelsus Eestis Euroopa Liidu mitmekeelsuse ideaali taustal. (Dissertationes de mediis et communicationibus Universitatis Tartuensis 9.) Tartu: Tartu Ülikooli Kirjastus.

Tuglas, Friedebert 2001 [1917]. Soome sild (esialgne pealkiri: „Aja küsimused” II. Uus Postimees 8. XII 1917, nr 3). - F. Tuglas, Kogutud teosed, kd 9. Kriitika V. Kriitika VI. Järelsõnad August Eelmäe ja Maie Kalda, kommentaarid A. Eelmäe, Ülle Kurs ja M. Kalda. Toimetanud Ü. Kurs. Tallinn: Underi ja Tuglase Kirjanduskeskus, lk 66-71.

Un d u s k, Jaan 2014. Iseseisvusmanifesti intertekstuaalsus. - Iseseisvusmanifest. Artikleid, dokumente ja mälestusi. Koost Tõnu Tannberg, Ago Pajur. Tartu: Rahvusarhiiv, lk 19-52.

Õ is, Ülle 2014. 6.-8. klassi õpilaste soome keele õppimise motivatsioon ja soome keele õppes kasutatavad enese motiveerimise strateegiad. Magistritöö. Tallinna Ülikool, Kasvatusteaduste Instituut.

\section{The Finnish-Estonian linguistic bridge in the $21^{\text {st }}$ century}

Keywords: knowledge of language(s), multilingualism, foreign language learning, Finnish language learning, language prestige

Traditionally, the metaphor of a Finnish-Estonian „linguistic bridge” has been used to refer to the competence in both languages on either side of the Gulf of Finland. The focus of this article is on the teaching of and competence in Finnish on the Estonian side. Over the recent 75 years the numbers of the Estonian people skilled in Finnish has grown from $0.5 \%$ of the population in 1934 to $12.9 \%$ in 2011, that is from 5729 to 167315 people. This growth of Finnish proficiency in Estonians has to do with their close Finnish contacts, including working in Finland. Although most of the Finnish has been acquired outside formal education, the language has been available at schools as a third (less as a fourth) foreign language and since 2011 as a second (B) foreign language. By the 2015/2016 academic year there were four schools in Estonia with a practical experience in teaching Finnish as a B foreign language, while the number of students receiving or having received such education was 216.

The aim of the study was to analyse why the students have chosen Finnish as their B foreign language, in particular, whether Finnish was considered easier or more difficult to learn than some other foreign language, whether Finnish has a higher prestige, or whether the choice was mainly motivated by a hope to find better work.

Traditionally, Estonian formal education has included at least two compulsory foreign languages, while a number of general schools offer one or two in addition. The results of language learning considerably depend on the rank of the language among the other foreign languages taught at the particular school, as well as on the contents and number of lessons. Since 2011 the basic school curriculum allows teaching any foreign language that the school can afford and the students wish to learn. Before that the first and second foreign languages had to be chosen from a list of four (English, German, French and Russian). The rest, including Finnish, 
were mainly taught as a third, much less as a fourth foreign language. The legal option to teach any foreign language as the second foreign language has mainly been realised by choosing Finnish.

In the 2011/2012 academic year Finnish was introduced as the second foreign language in the sixth form at four general schools. In April 2016 we made up a questionnaire of 13 items and emailed it, with brief instructions enclosed, to the Finnish teachers of those schools, targeting their new students. The results were received by ordinary mail in May and June, same year, yielding a total of 188 filled-in questionnaires returned from $87 \%$ of the 216 students taking Finnish as the second foreign language in those four basic schools. Of the 188 respondents 60 came from Jõgeva, 13 from Tartu, 52 from Pärnu and 63 from Viljandi, aged from 11 to 16 , with girls (53\%) slightly outnumbering boys (47\%).

We analysed the responses using a combined approach. The questions assuming free formulation of answers were subjected to qualitative inspection, while those assuming a numerical answer were approached statistically.

According to the results the most important language of communication, according to the young respondents, is English. However, proficiency in other languages is also appreciated, especially in Finnish for communication with Finns. Nearly one in every three respondents considered the relative similarity of Finnish and Estonian a condition facilitating learning.

The authors of the article believe that learning and teaching Finnish as well as Estonian on both sides of the Gulf continues to be necessary and topical in the interest of preserving the multilingual tradition and the linguistic bridge-building.

Tõnu Tender (b. 1965), PhD, Institute of the Estonian Language, Director, tonu.tender@eki.ee

Sven-Erik Soosaar (b. 1973), MA, Institute of the Estonian Language, Senior Lexicographer, svenerik@eki.ee 